\title{
Anti-EPO and anti-NESP antibodies raised against synthetic peptides that reproduce the minimal amino acid sequence differences between EPO and NESP
}

\author{
E. Giménez • C. de Bolós · V. Belalcazar • D. Andreu • \\ E. Borrás • B. G. De la Torre $\cdot$ J. Barbosa $\cdot$ J. Segura • \\ J. A. Pascual
}

Received: 21 February 2007 / Revised: 26 April 2007 / Accepted: 27 April 2007 / Published online: 30 May 2007

(C) Springer-Verlag 2007

\begin{abstract}
Erythropoietin (EPO) is a hormone that regulates red blood cell production. Recombinant human EPO (rHuEPO) and NESP (novel erythropoiesis stimulating protein) have been produced for therapeutic purposes and also to improve sports performance. The primary sequences of rHuEPO and NESP differ by just five amino acids. Due to the high homology, no antibodies that are able to discriminate between both molecules have been obtained until now. The aim of the present work was to design synthetic peptides corresponding to the sequence that differs between EPO and NESP (87-90aa), that can then be used as immunogens to develop specific rabbit polyclonal antibodies for selectively detecting EPO and NESP. Three peptides were synthesized: EPO (81-95), NESP (8195), and NESP (86-104), and these were coupled to KLH
\end{abstract}

V. Belalcazar J J. Segura $\cdot$ J. A. Pascual

Unitat de Farmacologia, IMIM-Hospital del Mar,

Dr. Aiguader 88,

08003 Barcelona, Spain

C. de Bolós $(\square)$

Unitat de Biologia Cel-lular i Molecular, IMIM-Hospital del Mar,

Dr. Aiguader 88,

08003 Barcelona, Spain

e-mail: cbolos@imim.es

E. Giménez • J. Barbosa

Departament de Química Analítica, Universitat de Barcelona,

Diagonal 647,

08028 Barcelona, Spain

D. Andreu $\cdot$ E. Borrás $\cdot$ B. G. De la Torre

Unitat de Proteòmica i Química de Proteïnes, Departament de

Ciències Experimentals i de la Salut, Universitat Pompeu Fabra,

Dr. Aiguader 88,

08003 Barcelona, Spain and OVA for immunization and screening purposes, respectively. The sera obtained were tested by ELISA on synthetic peptide-OVA conjugates and purified by immunoaffinity chromatography against the corresponding synthetic peptide. The specific purified antibodies were characterized by ELISA, SDS-PAGE, and isoelectric focusing, followed by western blot. Antisera raised against EPO (81-95) recognized rHuEPO but not NESP. In contrast, anti-NESP (84-106) sera gave a specific antiNESP response only after immunoaffinity purification on a NESP (86-91) column. An efficient strategy for generating specific antibodies against EPO and NESP can be achieved by selecting suitable synthetic peptides. The antibodies obtained are able to differentiate between $\mathrm{rHuEPO}$ and NESP, and may be particularly useful for screening purposes in both therapeutic and antidoping contexts.

Keywords Erythropoietin - NESP - Synthetic peptides . Polyclonal antibodies

$\begin{array}{ll}\begin{array}{l}\text { Abbreviations } \\ \text { aa }\end{array} & \begin{array}{l}\text { amino acid } \\ \text { bovine serum albumin } \\ \text { BSA }\end{array} \\ \begin{array}{l}\text { eLISyme-linked immunosorbent assay } \\ \text { erythropoietin }\end{array} \\ \text { EPO } & \begin{array}{l}\text { high-performance liquid chromatography } \\ \text { human immunodeficiency virus }\end{array} \\ \text { HPLC } & \text { immunoaffinity chromatography } \\ \text { HIV } & \text { immunoelectrofocusing } \\ \text { IAC } & \text { sodium dodecyl sulfate-polyacrylamide } \\ \text { IEF } & \begin{array}{l}\text { gel electrophoresis } \\ \text { keyhole limpet hemocyanin } \\ \text { matrix-assisted laser desorption ionization/ } \\ \text { time-of-flight }\end{array} \\ \text { KLH } & \end{array}$




$\begin{array}{ll}\text { MBS } & \begin{array}{l}\text { 3-maleimidobenzoic acid } N \text {-hydroxysucci- } \\ \text { nimide ester } \\ \text { novel erythropoiesis stimulating protein } \\ \text { ovalbumin }\end{array} \\ \text { NESP } & \text { OVA }\end{array}$

\section{Introduction}

Erythropoietin (EPO) is a hormone mainly produced by the peritubular cells in the adult human kidney cortex [1] that regulates red blood cell production [2]. Human EPO is a glycoprotein approximately $30 \mathrm{kDa}$ in size [3], and about $40 \%$ of its total molecular mass corresponds to three Nlinked (Asn24, Asn38, Asn83) and one O-linked (Ser126) carbohydrate chains attached to the polypeptide backbone. Recombinant human EPO (rHuEPO), first obtained in 1985 [1], differs from native EPO in its carbohydrate structure [4]. rHuEPO has been used extensively to treat certain forms of anemia associated with chronic renal failure, HIV infection, rheumatoid arthritis, premature birth, and cancer [5]; and has also become popular among endurance sport disciplines as a performance-enhancing agent [6, 7]. A hyperglycosylated analog of EPO, named NESP (novel erythropoiesis stimulating protein), has been obtained more recently [8]. This recombinant analog, which is also produced in hamster ovary cells (CHO), differs from rHuEPO by five amino acid residues (Ala30Asn, His32Thr, Pro87Val, Trp88Asn and Pro90Thr). The presence of two new asparagines amidst the consensus sequence Asn-Xxx$\mathrm{Ser} / \mathrm{Thr}$ makes the additional attachment of two extra Nlinked oligosaccharide chains, each containing up to four terminal sialic acid residues, possible. These modifications increase the molecular mass of NESP to approximately $37 \mathrm{kDa}$ and the number of sialic acid residues up to 22 $[5,8]$. In NESP, just like other glycoproteins, the increase in the number of sialic acid residues results in a longer circulating half-life and a greater biological activity compared to rHuEPO. Consequently, NESP can be administered once a week in order to improve the quality of life for patients [5].

Until now, a large number of monoclonal and polyclonal anti-human EPO-specific antibodies have been obtained and used in several techniques in order to detect EPO in biological samples from chronic kidney disease patients [9], as well as in a method used for doping control [6]. Also, anti-EPO antibodies have been used in capillary electrophoresis to detect and preconcentrate EPO in order to improve on current methods of detection [10, 11]. Antibodies that are able to discriminate between EPO and NESP, however, have not been described thus far.

The aim of this work was to obtain rabbit polyclonal antibodies that are able to differentiate between EPO and
NESP, in order to increase detection selectivity. For this purpose, peptides corresponding to the region (81-104) with the most sequence differences between rHuEPO and NESP were synthesized and used as immunogens. The specificity of the corresponding antibodies in recognizing $\mathrm{rHuEPO}$ and NESP molecules was assessed using several immunotechniques.

\section{Experimental}

\section{Erythropoietin samples}

rHuEPO samples were obtained from Eprex ${ }^{\circledR}$ (JanssenCilag, High Wycombe, UK). Each prefilled syringe contained 10,000 IU of epoetin alfa, $0.03 \%$ Tween 80 , $0.5 \%$ glycine, and $1 \mathrm{ml}$ of phosphate buffer. $\mathrm{rHuEPO}$ from the European Pharmacopoeia was used for IEF experiments, and each sample vial contained $250 \mu \mathrm{g}$ of rHuEPO (an equimolar mixture of epoetin alfa and beta). NESP (Darbepoetin alfa) was obtained from Aranesp ${ }^{\circledR}$ (Amgen, Thousand Oaks, CA, USA), and each prefilled syringe contained $20 \mu \mathrm{g}$ of NESP.

Peptide synthesis and coupling

Peptides corresponding to the EPO (81-95) sequence, its homologous NESP (81-95) and NESP (86-104), as well as the NESP (86-91)-Ahx affinity probe (Table 1) were prepared in C-terminal carboxamide form by solid-phase synthesis methods on $0.1 \mathrm{mmol}$ Rink amide-functionalized polyethyleneglycol-polystyrene. All sequences had an extra Cys residue at the $\mathrm{C}$-terminus to allow conjugation to either carrier protein (first three peptides) or IAC resin (Nesp (8691)-Ahx). This latter peptide also had an additional spacer residue of 6-aminohexanoic acid (Ahx) next to the Cys. The sequences were assembled in an Applied Biosystems 433 instrument running optimized $\mathrm{Fmoc} / \mathrm{tBu}$ chemistry that included (i) piperidine-DMF (1:4) deprotection, and (ii) couplings with $1 \mathrm{mmol}(10 \mathrm{eq})$ each of Fmoc amino acid, 2-(1H-benzotriazol-1-yl)-1,1,3,3-tetramethyluronium hexafluorophosphate and 1- $N$-hydroxybenzotriazole, in the presence of $2 \mathrm{mmol} N, N$-diisopropylethylamine in $N, N$ dimethylformamide. Final deprotection and cleavage from the solid support were performed with trifluoroacetic acid/ thioanisole/water/phenol/ethanedithiol (82.5:5:5:5:2.5) for $3.5 \mathrm{~h}$ at room temperature. The crude peptides were purified by reverse-phase preparative HPLC on $\mathrm{C}_{18}$ silica. Homogeneous fractions ( $>95 \%$ by analytical HPLC) were pooled to give materials of satisfactory composition and mass by amino acid analysis and MALDI-TOF mass spectrometry, respectively. For immunization and screening purposes, the three peptides were coupled to either keyhole limpet 
Table 1 Sequence, chemical data and conjugation ratios of the synthesized peptides used for the production and purification of antibodies against rHuEPO and NESP

\begin{tabular}{|c|c|c|c|c|c|}
\hline \multirow[t]{2}{*}{ Name } & \multirow[t]{2}{*}{ Amino acid sequence } & \multirow[t]{2}{*}{$\operatorname{HPLC}\left(t_{\mathrm{R}}, \min \right)$} & \multirow[t]{2}{*}{ MALDI-TOF MS ${ }^{\mathrm{b}}$} & \multicolumn{2}{|c|}{ Conjugation ratio } \\
\hline & & & & KLH & OVA \\
\hline EPO (81-95) & LVNSSQPWEPLQLHVC-NH ${ }_{2}$ & 6.0 & $1849.1(1848.94)$ & 1044.2 & 11.3 \\
\hline NESP (81-95) & LVNSSQVNETLQLHVC-NH ${ }_{2}$ & 4.8 & $1782(1782.91)$ & 1916.2 & 6.2 \\
\hline NESP (86-104) & QVNETLQLHVDKAVSGLRSC-NH ${ }_{2}$ & 4.8 & $2196.3(2196.15)$ & 1367.3 & 7.0 \\
\hline $\operatorname{NESP}(86-91)-A h x$ & QVNETL-Ahx-C-NH ${ }_{2}$ & 2.9 & $702.2(702.37)$ & - & - \\
\hline
\end{tabular}

${ }^{\mathrm{a}}$ Luna $\mathrm{C}_{18}$ (Phenomenex, Torrance, CA, USA) column, $3 \mu \mathrm{m}$ particle size, $50 \times 4.6 \mathrm{~mm}$; elution with linear $5-95 \%$ gradient of solvent $\mathrm{A}$ into B over $15 \mathrm{~min}$; solvent A: $0.045 \%(\mathrm{v} / \mathrm{v})$ trifluoroacetic acid in water; solvent B: $0.036 \%(\mathrm{v} / \mathrm{v})$ trifluoroacetic acid in acetonitrile

${ }^{\mathrm{b}} \mathrm{m} / \mathrm{z}$ observed; in parentheses, calculated $\mathrm{MH}^{+}$value

hemocyanin (KLH) or ovalbumin (OVA) using 3-maleimidobenzoic acid $N$-hydroxysuccinimide ester (MBS) and glutaraldehyde conjugation chemistries, respectively. The peptide content of the conjugates was determined by amino acid analysis.

Immunization schedule

Two New Zealand rabbits were immunized with $200 \mu \mathrm{g}$ of each synthetic peptide-KLH conjugate in MPL-TDM adjuvant (Sigma, St. Louis, MO, USA) every two weeks, and were boosted monthly after four immunizations. Animals were bled from the auricular artery, seven days after each immunization, starting from the third. Serum samples were stored frozen at $-40{ }^{\circ} \mathrm{C}$ until used. Animal protocols were approved by the CEEA (Ethical Comitee of Animal Experimentation) of the Institution.

\section{Enzyme-linked immunosorbent assays (ELISA)}

ELISA assays were performed on 96-well plates (MaxiSorp, Nunc, Roskilde, Denmark). Wells were coated with $50 \mu \mathrm{l}$ of the different antigens (peptide-ovalbumin conjugate, rHuEPO or NESP) at $10-40 \mu \mathrm{g} / \mathrm{ml}$ in PBS and incubated at $37{ }^{\circ} \mathrm{C}$ for $1 \mathrm{~h}$. Unbound sites were blocked with PBS-1\% gelatin for $30 \mathrm{~min}$. Fifty microliters of total antisera or purified specific antibodies, diluted in PBS$0.1 \%$ Tween 20 (PBS-T), were added and incubated for $1 \mathrm{~h}$ at $37^{\circ} \mathrm{C}$. After washing, $50 \mu \mathrm{l}$ of alkaline phosphatase-swine anti-rabbit immunoglobulins (Dako, Glostrup, Denmark) diluted $1 / 1000$ were added for $1 \mathrm{~h}$ at $37^{\circ} \mathrm{C}$. Reactions were developed with $50 \mu$ of 4-methylumbelliferyl-phosphate (Sigma) at $1 \mathrm{mg} / \mathrm{ml}$ in triethanolamine buffer $(\mathrm{pH} 9.5)$ for $30 \mathrm{~min}$ at room temperature, and fluorescence was measured by excitation at $360 \mathrm{~nm}$ and emission at $460 \mathrm{~nm}$ in a Cytofluor $^{\mathrm{TM}} 2350$ (Millipore, Billerica, MA, USA). Preimmune rabbit sera were used as the negative control. In some experiments, rHuEPO and NESP were reduced and alkylated before coating. For reduction, samples were diluted in PBS containing $10 \mathrm{mM}$ DTT and incubated at $56{ }^{\circ} \mathrm{C}$ for
$30 \mathrm{~min}$, and then alkylated with $50 \mathrm{mM}$ iodoacetamide for $30 \mathrm{~min}$ at room temperature in the dark. Finally, alkylated glycoproteins were desalted with Ultrafree-MC $10 \mathrm{kDa}$ (Millipore).

Immunoaffinity chromatography (IAC)

Antipeptide antibodies were purified by IAC against the corresponding peptides. The synthetic peptides were coupled to EAH Sepharose 4B (Amersham Biosciences, Piscataway, NJ, USA) at $1 \mathrm{mg} / \mathrm{ml}$ using $\mathrm{MBS}$ as a bifunctional crosslinking agent.

Antipeptide antisera, diluted $1 / 3$ in $10 \mathrm{mM}$ Tris- $\mathrm{HCl} \mathrm{pH}$ 7.6, were passed through the column 4-5 times (postcolumn antiserum). After washing with $10 \mathrm{mM}$ Tris- $\mathrm{HCl}$ and $0.5 \mathrm{M} \mathrm{NaCl} \mathrm{pH} 7.6$ to eliminate the nonspecifically retained fraction (washing fraction), bound antibodies were eluted with $100 \mathrm{mM}$ glycine- $\mathrm{HCl} \mathrm{pH} 2.5$ (elution fractions). Eluted fractions were immediately neutralized with $1 \mathrm{M}$ Tris and kept frozen at $-20{ }^{\circ} \mathrm{C}$ until use.

\section{SDS-PAGE and western blot}

rHuEPO and NESP were applied to $10 \%$ SDS-PAGE running gels and transferred onto nitrocellulose membranes (Protran, Schleicher and Schuell, Dassel, Germany). In some cases, the immobilized glycoproteins were partially deglycosylated by incubating the membrane with $10 \mathrm{mM} \mathrm{NaIO}_{4}$ in $25 \mathrm{mM}$ sodium acetate buffer $\mathrm{pH} 4.5$ for $1 \mathrm{~h}$ at room temperature in the dark. Non-specific binding sites were blocked using PBST-1\% BSA. Immunoblotting was performed by incubating anti-EPO (81-95) and anti-NESP (86-104) antibodies for $90 \mathrm{~min}$ (diluted 1/20-1/100). After washing with PBS-T, anti-rabbit-biotin (Dako) diluted 1/3000 was added for $1 \mathrm{~h}$, and after washing, streptavidin-horseradish peroxidase (HRP) (Zymed, San Francisco, CA, USA) diluted 1/3000 for $45 \mathrm{~min}$. Finally, reactions were developed using ECL reagent (Amersham). Pre-immune rabbit sera and a commercial polyclonal anti-EPO antibody (Sigma, ref. E0271) were used as negative and positive controls, respectively. 
Immunoelectrofocusing (IEF)

IEF was performed as described previously by Lasne et al. $[6,12]$. In brief, rHuEPO and NESP were applied on a polyacrylamide gel $(T=5 \%, \mathrm{C}=3 \%, 7 \mathrm{M}$ urea $)$ with a $\mathrm{pH}$ range of 2-6. The samples were focused at a constant power of $1 \mathrm{~W} / \mathrm{cm}$ of the gel length until $3600 \mathrm{Vh}$ at $8{ }^{\circ} \mathrm{C}$ using a flat system (Multiphor II Electrophoresis system, Amersham-Pharmacia). After the IEF, the proteins were transferred $\left(0.8 \mathrm{~mA} / \mathrm{cm}^{2}, 30 \mathrm{~min}\right)$ to a polyvinylidene difluoride membrane (PVDF) using a basic transfer buffer (25 mM Tris-192 mM glycine). The membranes were incubated with the antibody directly or after pretreatment with $10 \mathrm{mM} \mathrm{NaIO}_{4}$ in $25 \mathrm{mM}$ sodium acetate buffer, $\mathrm{pH}$ 4.5 , in order to produce partial deglycosylation.

The purified anti-EPO (81-95) and anti-NESP (86-104) antibodies were diluted (1/35) with PBS-T and incubated overnight at room temperature. The polyclonal anti-EPO antibody from Sigma (ref. E0271) was used at 1/500 dilution with PBS-skim milk (1\%) and incubated for $1 \mathrm{~h}$. The monoclonal anti-human EPO antibody (clone 9C21D11, R\&D Systems) was evaluated at different dilutions $(1 / 1000,1 / 500,1 / 400,1 / 200$ and 1/100) and incubated for $1 \mathrm{~h}$ in all cases, and the monoclonal antihuman EPO antibody (clone AE7A5, R\&D Systems, Minneapolis, MN, USA), which is used as primary antibody in the IEF method for detecting urinary EPO during routine doping control, was used as a positive control under conditions that are described elsewhere [6].

After washing, only the membranes incubated with commercial antibodies (Sigma) were subjected to the double blotting procedure [12]. The antibodies were blotted $\left(0.8 \mathrm{~mA} / \mathrm{cm}^{2}, 30 \mathrm{~min}\right)$ to a second PVDF membrane using an acidic transfer buffer $(0.7 \%$ acetic acid). In accordance with the origin of the primary antibody, anti-rabbit-biotin $(1 / 3000)$ or anti-mouse-biotin (1/4000) were used for $1 \mathrm{~h}$ at room temperature. Finally, the membrane was incubated with streptavidin-HRP (Biospa, SPA, Milano, Italy) for $1 \mathrm{~h}$.

The chemiluminiscent light was produced by the addition of the peroxidase substrate (SuperSignal West Femto stable peroxide, Pierce, Rockford, IL, USA). The light was detected using a CCD camera (luminescent image analyzer LAS-1000, Fujifilm, Tokyo, Japan).

\section{Results}

Peptide selection

Peptides from the region containing three of the five amino acids that differ between EPO and NESP were selected as antigens in an attempt to raise antibodies that are able to differentiate these two glycoproteins. Their amino acid sequences, chemical data, and the conjugation rates with KLH and OVA are shown in Table 1. First, two 15-residue peptides containing the EPO- (81-95) and NESP- (81-95) specific sequences were synthesized. A cysteine residue was added to the $\mathrm{C}$-terminal part of each peptide to allow conjugation to KLH and OVA.

Animals immunized with NESP (81-95)-KLH conjugate $(n=2)$ did not develop antibody response to the peptide. Hence, a second NESP peptide was designed and synthesized (NESP (86-104)). As shown in Table 1, this peptide was longer than NESP (81-95) and it had three differing amino acids in the C-terminal region, which should make specific immunological recognition more likely.

Antisera titration and purification by immunoaffinity chromatography

In order to analyze the levels of the antipeptide antibodies, pre- and post-immunization anti-EPO (81-95) and antiNESP (86-104) sera were tested by ELISA using immobilized peptide-OVA conjugates at $10 \mu \mathrm{g} / \mathrm{ml}$. No differences in the antibody titer and the specificity were obtained between animals immunized with the same peptide-
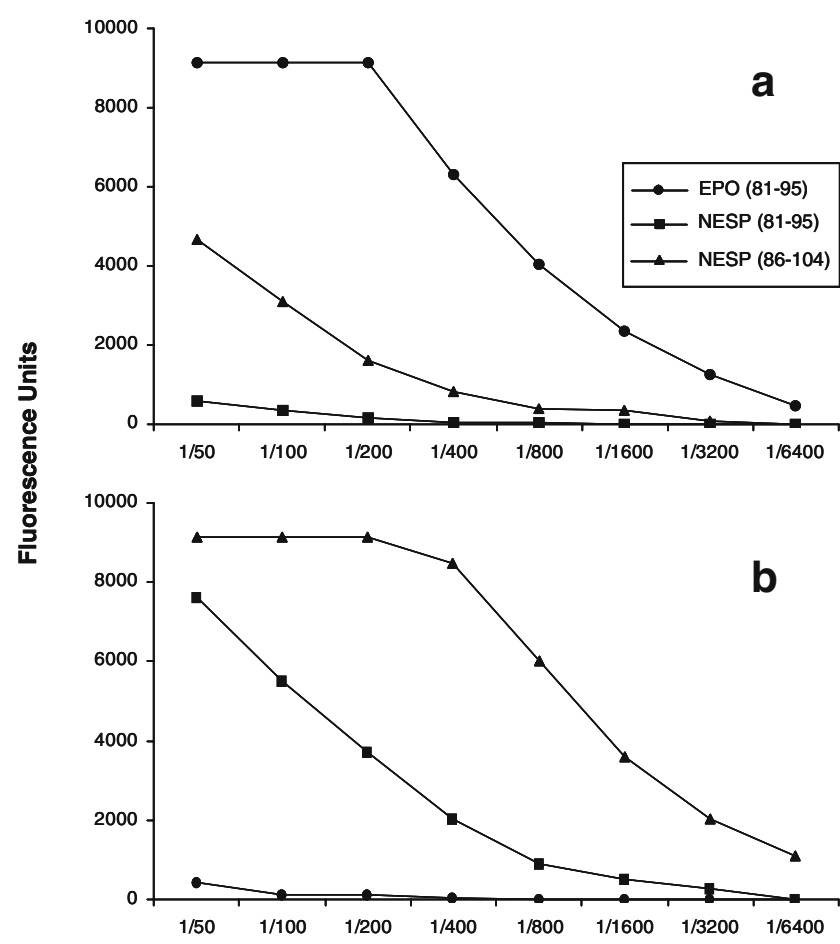

Antisera dilution

Fig. 1a, b Titration of the antisera against the peptides used for immunization. a EPO (81-95) antiserum; b NESP (86-104) antiserum. Circles, response to EPO (81-95) peptide; squares, response to NESP (81-95) peptide; triangles, response to NESP (86-104) peptide. ELISA well plates were coated with a $10 \mu \mathrm{g} / \mathrm{ml}$ peptide-OVA conjugate solution 
Fig. 2a, b Antipeptide antibody recognition of rHuEPO and NESP in their native state (solid columns) and reduced-alkylated state (hatched columns). rHuEPO columns are indicated in gray and NESP columns in black. ELISA test: well plates were coated with $10 \mu \mathrm{g} / \mathrm{ml}$ of rHuEPO and NESP and the antipeptide antibodies were diluted 1/20. a) EPO (81-95) antibody recognition; b) NESP (86-104) antibody recognition
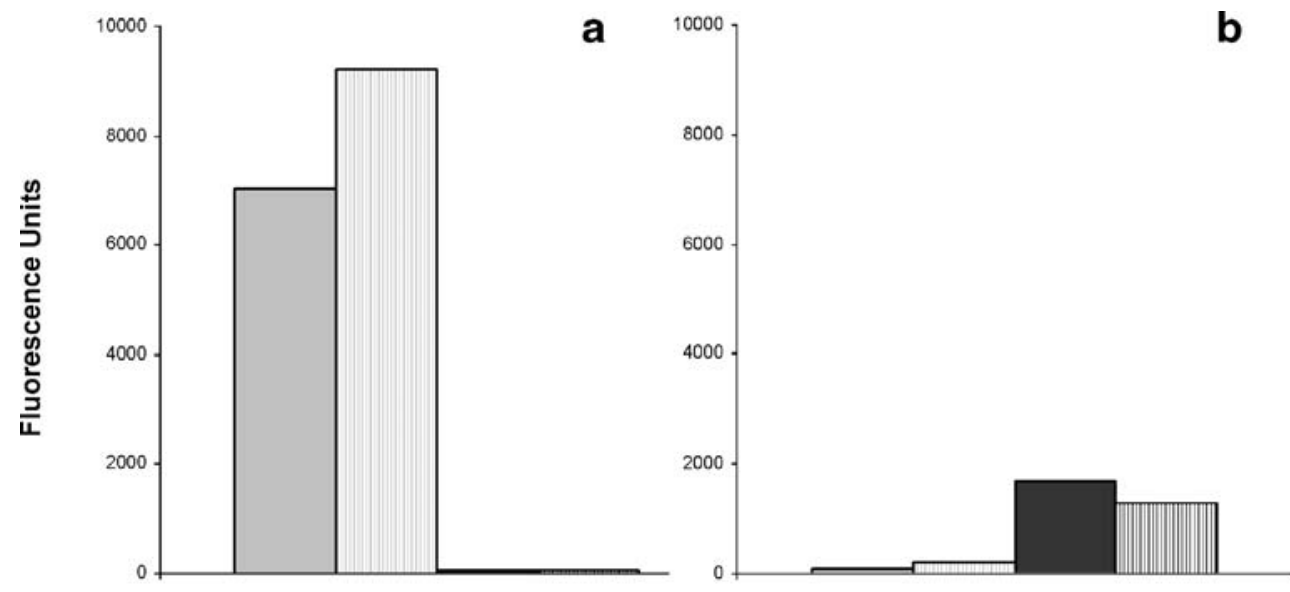

rHuEPO $\square$ rHuEPO reduced and alkylated conjugate. As shown in Fig. 1a, EPO (81-95) antisera strongly reacted with the EPO (81-95) peptide, showed a weaker reactivity for the NESP (86-104) peptide, and did not recognize the NESP (81-95) peptide. In contrast, antiNESP (86-104) sera recognized the NESP (86-104) peptide, recognized the NESP (81-95) peptide to a lower extent, and did not recognize the EPO (81-95) peptide (Fig. 1b).

The specific anti-peptide antibodies from EPO (81-95) and NESP (86-104) antisera were purified by immunoaffinity chromatography where the corresponding synthetic peptide was immobilized to EAH Sepharose 4B. The different purification fractions were tested by ELISA using the peptide-OVA conjugates, as described. The flowthrough (post-column) and washing fractions did not react with the corresponding peptides (data not shown), confirming that all of the antipeptide antibodies were retained by the peptide-EAH Sepharose 4B columns. Furthermore, all of the antipeptide antibodies were found in the first six elution fractions (data not shown). These results demonstrated that immobilized EPO (81-95) and NESP (86-104) peptides efficiently retained all of the anti-EPO (81-95) and anti-NESP (86-104) antibodies from whole antiserum.

\section{rHuEPO and NESP recognition by ELISA}

The capacity of the purified antipeptide antibodies to recognize entire $\mathrm{rHuEPO}$ and NESP were first tested by
ELISA assays. The native rHuEPO and NESP glycoproteins and the reduced and alkylated forms were immobilized on 96-well plates. The results, shown in Fig. 2a and b, indicate that antibodies raised against EPO (81-95) are able to recognize rHuEPO in its native state. Reduction and alkylation enhanced their ability to detect rHuEPO, indicating better exposure of the recognized epitopes after denaturation. In addition, anti-EPO (81-95) antibodies did not react with either the native NESP or with the reduced and alkylated form (Fig. 2a). These results suggest a high specificity of the anti-EPO (81-95) antibodies for the region of the primary EPO sequence containing the three amino acids (87-88, 90), which differs between EPO and NESP. In contrast, anti-NESP (86-104) antibodies recognized both NESP and rHuEPO, although rHuEPO was recognized to a lesser degree (Fig. 2b). After reduction and alkylation, the reactivity of the antibodies did not improve.

\section{rHuEPO and NESP recognition by SDS-PAGE} and western blot

The specificities of the purified antibodies were also assessed by SDS-PAGE/western blot using rHuEPO and NESP. Figure 3, panels 3 and 4, show that anti-EPO (8195) antibodies only recognized rHuEPO (and not NESP), whereas anti-NESP (86-104) antibodies detected rHuEPO and NESP, which confirmed the results obtained by ELISA. The commercial polyclonal anti-EPO antibody (Sigma) also

\section{3}
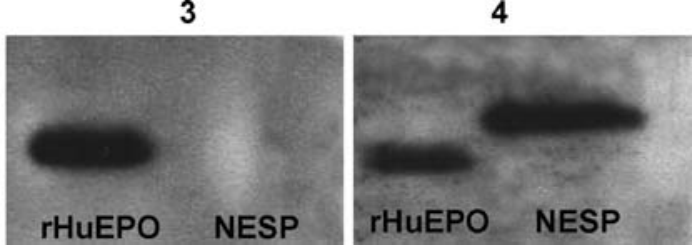

3, EPO (81-95) antibody diluted 1/100; 4, NESP (86-104) antibody diluted $1 / 100$. Wells contained $0.5 \mu \mathrm{g}$ of rHuEPO or NESP
Fig. 3 Recognition of rHuEPO and NESP by different antibodies after separation by SDS-PAGE and western blot detection. 1, Molecular weight standards; 2, commercial polyclonal anti-EPO (Sigma) at $1 \mu \mathrm{g} / \mathrm{ml}$; 
a

(1)

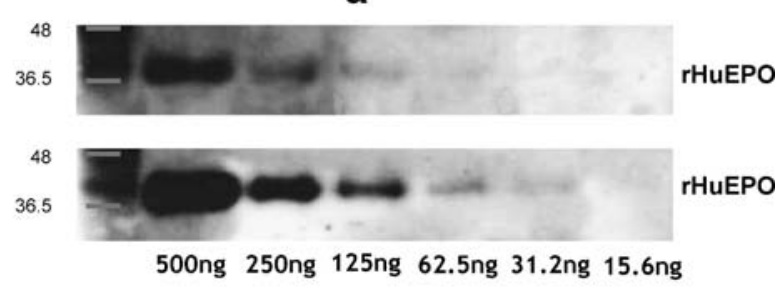

b

(1)

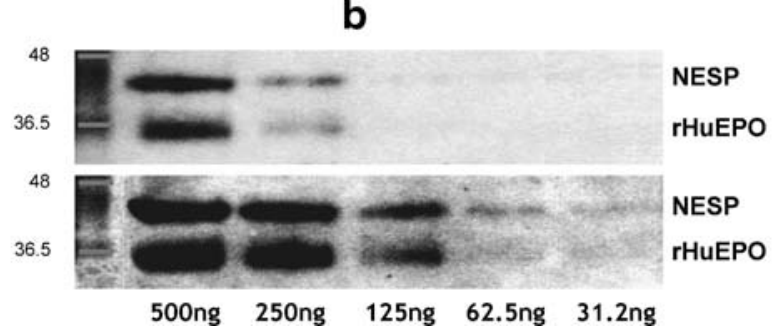

Fig. 4a, b Limits of detection for rHuEPO and NESP reached by SDS-PAGE and western blot using the obtained antipeptide antibodies and different treatments. EPO (81-95) antibody (a) and NESP (86-104) antibody (b) to reduced proteins (1) and reduced and partially deglycosylated proteins (2). Antipeptide antibodies were diluted $1 / 100$

recognized both rHuEPO and NESP glycoproteins (Fig. 3, panel 2).

The limits of detection for rHuEPO and NESP were determined using decreasing amounts of rHuEPO and NESP. In order to maximize the sensitivity of the antibodies, membrane-immobilized proteins were also partially deglycosylated using sodium periodate. As can be seen in Fig. 4, this treatment enhanced the detection, suggesting that the partial elimination of the carbohydrate chains improved the recognition of these glycoproteins by the corresponding antipeptide antibodies. Moreover, images obtained for low amounts of protein (62.5 and $31.2 \mathrm{ng}$ ) confirmed that anti-NESP (86104) antibodies had higher specificity for NESP (Fig. 4b). At 1/20 antibody dilution, it was possible to detect down to $7 \mathrm{ng}$ of NESP $(0.28 \mu \mathrm{g} / \mathrm{ml}$ of NESP $)$ with the anti-NESP (86-104) antibody and down to $15 \mathrm{ng}$ of $\mathrm{rHuEPO}(0.6 \mu \mathrm{g} / \mathrm{ml}$ of $\mathrm{rHuEPO}$ ) with the antibody against the EPO (81-95) peptide using reduced and partially deglycosylated glycoproteins (data not shown).

\section{NESP (86-91)-Ahx IAC purification}

In order to isolate the specific population of antibodies to NESP contained in the previously purified anti-NESP (86104) antibodies, the samples were passed through a column of immobilized NESP (86-91)-Ahx peptide (QVNETL region). The results shown in Fig. 5a indicate that most of the anti-NESP (86-104) antibodies were not retained by the NESP (86-91)-Ahx column, with the exception of a small fraction of the antibodies which eluted from fraction 3 to 6 , which specifically recognized the QVNETL sequence. The specificity of these antibodies to rHuEPO and NESP was evaluated by ELISA (data not shown) and SDS-PAGE/ western blot. Results shown in Fig. 5b indicate that the anti-NESP (86-104) antibodies were able to recognize both rHuEPO and NESP, whereas the NESP (86-91)-Ahxpurified antibodies selectively detected NESP. Moreover, this recognition of NESP was improved after partial deglycosylation using sodium periodate. Although the signal obtained for the blots with the NESP (86-91)-Ahxpurified antibodies was rather faint, the results suggest that the immunization with NESP (86-104)-KLH was able to induce a specific immune response against the QVNETLspecific sequence of NESP.

\section{rHuEPO and NESP recognition by IEF}

The specificities of the anti-EPO (81-95) and anti-NESP (86-104) polyclonal antibodies were also evaluated by IEF. Results indicate that antibodies to EPO (81-95) peptide kept their specificity for rHuEPO, while NESP was not detected (Fig. 6, panel 1). Interestingly, the antibodies to NESP (86-104) peptide, which detect both glycoproteins,

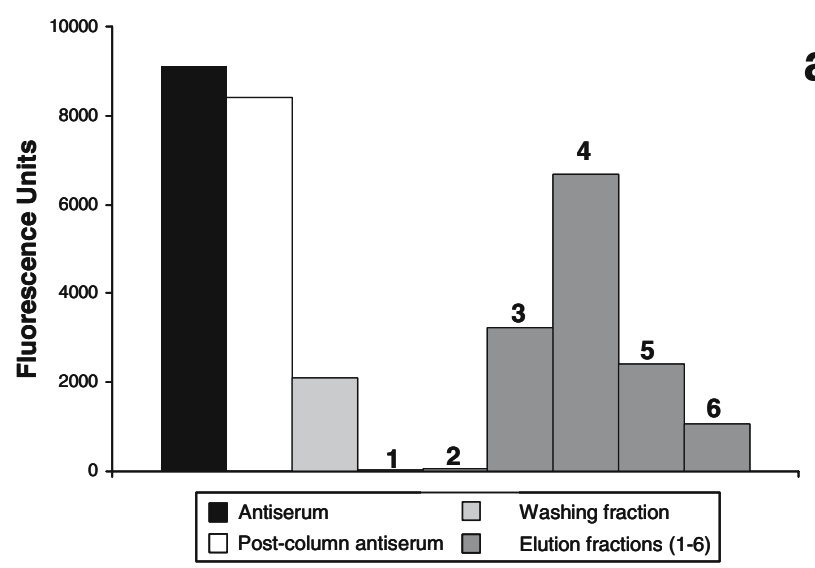

(1)

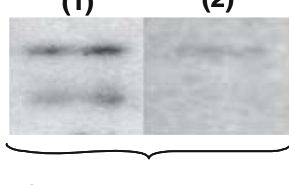

Glycosylated proteins
(1)

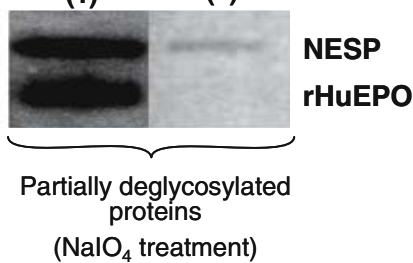

Fig. 5a, b Purification and characterization of NESP (86-104) antibodies purified by immunoaffinity chromatography using the synthetic peptide NESP (86-91)-Ahx. a NESP (86-91)-Ahx column behavior during purification of the NESP (86-104) antiserum. ELISA test: well plates were coated with a $10 \mu \mathrm{g} / \mathrm{ml}$ NESP (86-104)-OVA conjugate solution and each purification fraction diluted 1/240. b SDS-PAGE/ western blot of rHuEPO and NESP with NESP (86-104) antibodies purified with (1) NESP (86-104) column at 1/100 dilution and (2) NESP (86-91)-Ahx column at 1/60 dilution. Wells contained $250 \mathrm{ng}$ of rHuEPO and NESP 
Fig. 6 Comparison of the analysis of rHuEPO and NESP by IEF using different primary antibodies and conditions. 1, EPO (81-95) antibody at $1 / 35$ dilution; 2, NESP (86-104) antibody at $1 / 35$ dilution; both antibodies were evaluated under partial deglycosylation treatment. 3, polyclonal anti-EPO antibody from Sigma (E0271) at 1/500 dilution; 4, monoclonal anti-EPO antibody from R\&D (9C21D11) at 1/500 dilution under partial deglycosylation treatment; 5, monoclonal antiEPO antibody from R\&D (AE7A5) at 1/1000 dilution
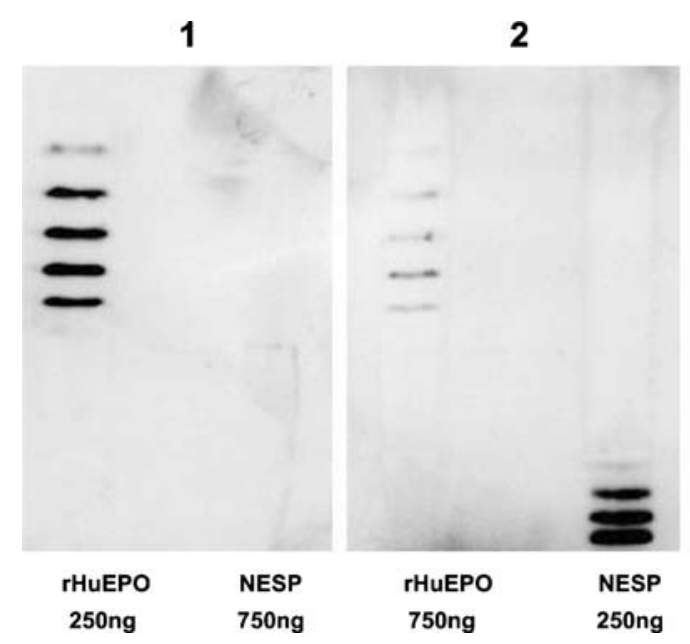

3

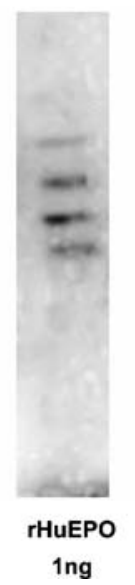

4

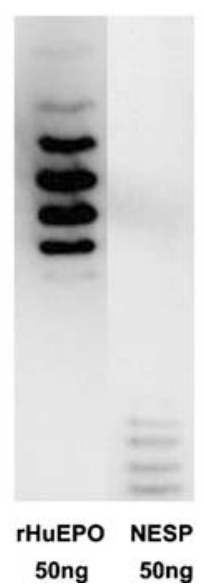

5

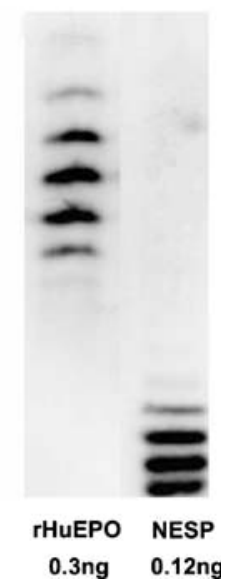

showed a much higher sensitivity for NESP than for rHuEPO (Fig. 6, panel 2). The antibodies had the same specificity, but the sensitivity was enhanced when the glycoproteins were partially deglycosylated with sodium periodate, corroborating the SDS-PAGE/western blot results (Fig. 6, panel 4).

The behavior of the obtained polyclonal antibodies was compared with commercially available antibodies. Both the anti-human EPO rabbit polyclonal antibody used as control in the SDS-PAGE/western blot experiments (Fig. 6, panel 3) and the monoclonal antibodies (clone AE7A5 and 9C21D11 from R\&D) recognized both $\mathrm{rHuEPO}$ and NESP under the IEF conditions; however, they differ in sensitivity. Monoclonal anti-human EPO (clone AE7A5) had limits of detection of better than $0.3 \mathrm{ng}$ for $\mathrm{rHuEPO}$ or $0.1 \mathrm{ng}$ for NESP at 1/1000 dilution (Fig. 6, panel 5), whereas the monoclonal anti-human EPO 9C21D11 showed much lower sensitivity but one that was greater for $\mathrm{rHuEPO}$ than for NESP at 1/500 dilution (Fig. 6, panel 4). Under optimum conditions, including partial deglycosylation over the membrane, the limit of detection was $5 \mathrm{ng}$ for $\mathrm{rHuEPO}$ and $20 \mathrm{ng}$ for NESP (data not shown).

\section{Discussion}

Synthetic peptides corresponding to the N- and C-terminal sequences of EPO and NESP have been selected in several instances as immunogens. As the sequences of both glycoproteins in these regions are identical, antibodies that are currently available do not discriminate between EPO and NESP [6, 13-19].

In this work, we designed synthetic peptides of 15-19 amino acids which contain three of the amino acids that differ in EPO and NESP, in order to develop specific antiEPO and anti-NESP antibodies. In the case of the NESP (81-95) peptide, no specific immune response was obtained, probably due to the conformation acquired during the process of conjugation to KLH and the lower immunogenicity of the VNET (87-90) sequence compared with the specific EPO (81-95) peptide sequence PWEP. As previously reported, peptide immunogenicity is determined by factors such as coupling method, sequence length, hydrophilicity, accessibility, mobility, and protrusion [20]. In order to obtain anti-NESP specific polyclonal antibodies, we designed a new synthetic peptide-NESP (86-104)containing the specific NESP sequence VNET in the Cterminal region, which could potentially be more accessible to the B-cells. The antisera obtained recognize the NESP and $\mathrm{rHuEPO}$ glycoproteins, suggesting that the polyclonal sera contained a pool of specific antibodies that could potentially recognize several epitopes present in the peptide sequence. We isolated the antibodies that specifically recognized the VNET sequence of NESP using IAC with immobilized NESP (86-91)-Ahx peptide, which allowed us to obtain QVNETL-specific antibodies. These antibodies are able to recognize NESP in ELISA and western blot assays and they ignore the rHuEPO glycoprotein, indicating that our immunization-purification strategy is useful for obtaining polyclonal antibodies against the VNET sequence of NESP.

The recognition of $\mathrm{rHuEPO}$ and NESP by these antipeptide antibodies was improved by partial deglycosylation as well as reduction and alkylation. Results indicate that the epitopes recognized by the specific antibodies can be masked by the carbohydrate chains in the native and recombinant glycoproteins, and that the folding of the protein via two disulfide bonds can mask the sequences where the antibodies bind, as has been described for EPO [15] and other highly glycosylated proteins that can form oligomers, such as mucins [21, 22] and CD44 [23].

Polyclonal anti-EPO (81-95) and anti-NESP (86-104) antibodies were also tested on rHuEPO and NESP by IEF, which is the method currently used in doping control [6, 
10]. The IEF results agree with those obtained by ELISA and SDS-PAGE/western blot, confirming the specificity of the antibodies and also that the sensitivity is enhanced when the glycoproteins are partially deglycosylated. In comparison with commercially available antibodies, the polyclonal antibodies obtained in our study are sufficiently selective to differentiate EPO and NESP. Although their sensitivity is still low, and further studies are needed in order to analyze their reactivity when biological samples are used, this advantage should prove useful in fields such as doping or pharmaceutical control.

Acknowledgments This project has been carried out with the support of WADA and Plan Nacional DEP2005-00234 (Ministerio de Educación y Ciencia, Spain). The authors thank Marta Garrido and Daniel Moya for their excellent technical assistance.

\section{References}

1. Fried W (1995) Annu Rev Nutr 15:353-377

2. Krantz SB (1991) Blood 77:419-434

3. Fisher JW (2003) Exp Biol Med 228:1-14

4. Yuen CT, Storring PL, Tiplady RJ, Izquierdo M, Wait R, Gee CK, Gerson P, Lloyd P, Cremata JA (2003) Br J Haematol 121:511-526

5. Egrie JC, Dwyer E, Browne JK, Hitz A, Lykos MA (2003) Exp Hematology 31:290-299
6. Lasne F, Martin L, Crepin N, Ceaurriz J (2002) Anal Biochem 311:119-126

7. Pascual JA, Belalcazar V, de Bolós C, Gutiérrez R, Llop E, Segura J (2004) Ther Drug Monit 26:175-179

8. Egrie JC, Browne JK (2001) Nephrol Dial Transplant 16:3-13

9. Paoletti E, Cannella G (2006) J Am Soc Nephrol 17(Suppl 4): 74-77

10. Bornemann C, Burggraef T, Heimbuchel G, Hanisch FG, Winkels S (2003) Anal Bioanal Chem 376:1074-1080

11. Benavente F, Hernandez E, Guzman NA, Sanz-Nebot V, Barbosa J (2007) Anal Bioanal Chem 387:2633-2639

12. Lasne F (2001) J Immunol Methods 253:125-131

13. Amadeo I, Oggero M, Zenclussen ML, Robles L, Pereira D, Kratje R, Etcheverrigaray M (2004) J Immunol Methods 293:191-205

14. D'Andrea AD, Szklut PJ, Lodish HF, Alderman EM (1990) Blood $75: 874-880$

15. Elliott S, Chang D, Delorme E, Dunn C, Egrie J, Giffin J, Lorenzini T, Talbot C, Hesterberg L (1996) Blood 87:2714-2722

16. Goto M, Murakami A, Akai K, Kawanishi G, Ueda M, Chiba H, Sasaki R (1989) Blood 74(4):1415-1423

17. Sue JM, Sytkowski AJ (1983) Proc Natl Acad Sci USA 80:3651-3655

18. Sytkowski AJ, Donahue KA (1987) J Biol Chem 262:1161-1165

19. Sytkowski AJ, Fisher JW (1985) J Biol Chem 260:14727-14731

20. Barlow DJ, Edwards MS, Thornton JM (1986) Nature 322: 747-748

21. De Bolós C, Garrido M, Real FX (1995) Gastroenterology 109:723-734

22. Burchell J, Gendler S, Taylor-Papadimitriou J, Girling A, Lewis A, Millis R, Lamport D (1987) Cancer Res 47:5476-5482

23. Goodison S, Urdiqui V, Tarin D (1999) J Clin Mol Pathol 52:189-196 